\title{
Identifying the determinants of South Africa's extensive and intensive trade margins: A gravity model approach
}

\begin{tabular}{|c|c|}
\hline \multicolumn{2}{|c|}{$\begin{array}{l}\text { Authors: } \\
\text { Marianne Matthee } \\
\text { Maria Santana-Gallego }\end{array}$} \\
\hline \multicolumn{2}{|c|}{$\begin{array}{l}\text { Affiliations: } \\
{ }^{1} \text { School of Economics, } \\
\text { North-West University, } \\
\text { South Africa }\end{array}$} \\
\hline \multicolumn{2}{|c|}{$\begin{array}{l}{ }^{2} \text { Department of Applied } \\
\text { Economics, University of the } \\
\text { Balearic Islands, Spain }\end{array}$} \\
\hline \multicolumn{2}{|c|}{$\begin{array}{l}\text { Corresponding author: } \\
\text { Marianne Matthee, } \\
\text { marianne.matthee@nwu. } \\
\text { ac.za }\end{array}$} \\
\hline \multicolumn{2}{|c|}{$\begin{array}{l}\text { Dates: } \\
\text { Received: } 04 \text { Mar. } 2016 \\
\text { Accepted: } 10 \text { Jan. } 2017 \\
\text { Published: } 24 \text { Mar. } 2017\end{array}$} \\
\hline \multicolumn{2}{|c|}{$\begin{array}{l}\text { How to cite this article: } \\
\text { Matthee, M. \& Santana- } \\
\text { Gallego, M., 2017, } \\
\text { 'Identifying the determinants } \\
\text { of South Africa's extensive } \\
\text { and intensive trade margins: } \\
\text { A gravity model approach', } \\
\text { South African Journal of } \\
\text { Economic and Management } \\
\text { Sciences 20(1), a1554. } \\
\text { https://doi.org/10.4102/ } \\
\text { sajems.v20i1.1554 }\end{array}$} \\
\hline \multicolumn{2}{|c|}{$\begin{array}{l}\text { Copyright: } \\
\text { ( 2017. The Authors. } \\
\text { Licensee: AOSIS. This work } \\
\text { is licensed under the } \\
\text { Creative Commons } \\
\text { Attribution License. }\end{array}$} \\
\hline \multicolumn{2}{|l|}{ Read online: } \\
\hline 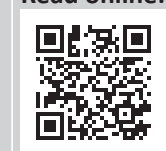 & $\begin{array}{l}\text { Scan this QR } \\
\text { code with your } \\
\text { smart phone or } \\
\text { mobile device } \\
\text { to read online. }\end{array}$ \\
\hline
\end{tabular}

Background: The significance of the paper is twofold. Firstly, it adds to the small but growing body of literature focusing on the decomposition of South Africa's export growth. Secondly, it identifies the determinants of the intensive and extensive margins of South Africa's exports - a topic that (as far as the authors are concerned) has not been explored before.

Aim: This paper aims to investigate a wide range of market access determinants that affect South Africa's export growth along the intensive and extensive margins.

Setting: Export diversification has been identified as one of the critical pillars of South Africa's much-hoped-for economic revival. Although recent years have seen the country's export product mix evolving, there is still insufficient diversification into new markets with high value-added products. This is putting a damper on export performance as a whole and, in turn, hindering South Africa's economic growth.

Methods: A Heckman selection gravity model is applied using highly disaggregated data. The first stage of the process revealed the factors affecting the probability of South Africa exporting to a particular destination (extensive margin). The second stage, which modelled trade flows, revealed the variables that affect export volumes (intensive margin).

Results: The results showed that South Africa's export product mix is relatively varied, but the number of export markets is limited. In terms of the extensive margin (or the probability of exporting), economic variables such as the importing country's GDP and population have a positive impact on firms' decision to export. Other factors affecting the extensive margin are distance to the market (negative impact), cultural or language fit (positive impact), presence of a South African embassy abroad (positive impact), existing free trade agreement with Southern African Development Community (positive impact) and trade regulations and costs (negative impact). In terms of the intensive margin (or the factors influencing the volume of exports), there are strong parallels with the extensive margin, with the exception being that the time involved in exporting has more of an impact than documentary requirements.

Conclusion: Among the factors contributing to South Africa's exports having largely developed in the intensive margin are a general lack of market-related information, infrastructural weaknesses (both of a physical and technological nature) and a difficult regulatory environment - all of which add to the cost and time involved in exporting. Policymakers have long spoken about the need for the country to diversify its export basket, but now talk about needs to give way to action. The government and its economic partners need to arrive at a common vision of an export sector that will be able to expand into new products and markets, be an active participant in global value chains and deliver sustainable jobs.

\section{Introduction}

Since the first democratic elections were held in 1994, the South African government has been intent on boosting employment in the country by encouraging higher and more inclusive economic growth. Industrialisation and export diversification have been part and parcel of this goal (Viviers et al. 2014). The Department of Trade and Industry (DTI) (2013:16) states:

\footnotetext{
... the growth and diversification of South African exports has been weak, with over half of all exports derived from the mining value chain. In order to stabilise growth it is important to diversify exports, including into higher value-added activities, and to improve overall competitiveness.
}

The World Bank (2014), in its analysis of South Africa's export competitiveness, states that it may be difficult for the country to revitalise its export sector. Firstly, South African exports have been 
underperforming, especially compared with its emerging market peers. Secondly, while the composition of South Africa's exports is changing, there is insufficient diversification into new and higher value products. Indeed, Matthee, Idsardi and Krugell (2016) reveal that since 1994, the highest export growth has been in non-fuel primary commodities (38\%), while medium-skill, technology-intensive manufactures have grown by $22 \%$. Resource-intensive manufactures have shown a serious decline in exports (around 50\%). Furthermore, the bulk of South Africa's export growth (more than $70 \%$ ) has been in the intensive margin (i.e. exports to existing trade partners) and the remainder in the extensive margin (i.e. diversification in terms of exporting firms, products or destinations) (Bezuidenhout et al. 2015; Matthee et al. 2016).

The above scenario is the result of both broad structural problems in the South African economy and largely uncontrollable global influences, such as the continuous decline in commodity prices in recent years and waning demand in traditional markets. In addition, various market access barriers, including the distance to export markets and high transport costs, have conspired to erode South Africa's export competitiveness and weakened the country's export growth potential (Steenkamp, Grater \& Viviers. 2015).

This paper aims to investigate a wide range of market access determinants that affect South Africa's export growth. The significance of the paper is twofold. Firstly, it adds to the small but growing body of literature focusing on the decomposition of South Africa's export growth. Secondly, it identifies the determinants of the intensive and extensive margins of South Africa's exports - a topic that (as far as the authors are concerned) has not been explored before.

The study's empirical framework is derived from the influential Melitz (2003) model, which is based on assumptions of firm heterogeneity in productivity and fixed costs when trade margins are analysed. More productive firms self-select into export destination markets (i.e. the extensive margin). In this regard, as firms exhibit heterogeneity in their productivity, only the more productive ones are able to generate sufficient operating profits in a destination market to cover the associated fixed costs and serve the market through exports (see also Chaney 2008; Crozet \& Koenig 2010; Helpman, Melitz \& Rubenstein 2008). Chaney (2008) states that a decrease in the fixed bilateral costs of trade (e.g. start-up costs) would positively affect the extensive margin (number of firms), while a decrease in the variable trade costs (e.g. transport costs) would increase both the extensive and intensive margins.

This paper uses the gravity model to analyse the pattern of South African exports at the product-level. Detailed productlevel data are used to determine the impact of trade costs and barriers on the number of firms exporting to different markets and the volume of exports to each market. To this end, the product-level data are decomposed per industry, and the impact of different aspects relating to market access (i.e. market capacity, trade facilitation and trade barriers) are assessed in terms of the authors' gravity model definition. This specification is estimated using the two-stage sample selection procedure proposed by Heckman (1979).

The rest of the paper is structured as follows: The next section discusses a brief literature overview. The 'Empirical specification' section presents the data and methodology used in the study. The 'Extensive and intensive margins of South African exports' section summarises the results of the empirical analysis and the 'Summary of key findings and concluding remarks' section summarises the key findings and provides some concluding remarks.

\section{Brief literature overview}

The heterogeneous nature and performance of firms has become a key focus area in international trade research (Melitz \& Redding 2012). According to Chaney (2008), firms are heterogeneous in their productivity levels. Moreover, when firms decide to export, they face both fixed and variable costs. Given that there is a threshold productivity level below which zero profits are yielded, only the more productive firms will find it profitable to export. On the one hand, a reduction in variable trade costs will affect both the intensive and extensive margins positively, because the threshold productivity level will drop and both the volume of export of existing exporting firms and the number of new exporting firms will increase. On the other hand, a reduction in fixed trade costs will not affect the intensive margin (the existing exporters have already paid this cost), but will induce new firms to enter the export field. In other words, it will have a positive effect on the extensive margin. Consequently, zero trade flows result from the impossibility of overcoming fixed costs that are necessary to establish trade.

The Melitz (2003) model makes it possible to endogenously calculate the number of firms that decide to export, which has created a new way of decomposing the observed trade flows into the extensive margin of trade (the number of exporting firms) and the intensive margin of trade (the volume of trade per exporter). This decomposition offers a coherent explanation for why only the most productive firms are involved in international trade. Because the study considers product-level exports to importing countries, zero trade flows arise when no firms in South Africa are productive enough to export to a particular destination.

A gravity model approach is used in the empirical analysis presented in this paper. The gravity model has been used in a plethora of empirical studies involving trade margins (see, e.g. Amurgo-Pacheco \& Pierola 2008; Crozet \& Koenig 2010; Felbermayr \& Kohler 2006; to name a few). These studies have used different adaptations of the model, estimators and focus points. For example, Lawless (2010) focuses on trade costs, Debaere and Mostashari (2010) on tariffs, Dutt, Mihov and Van Zandt (2011) on the World Trade Organization, Baier, Bergstrand and Feng (2013) on economic integration agreements and Johannsen and Martínez-Zarzoso (2014) on 
international arms transfers. Of more relevance to this particular study, Greenaway, Gullstrand and Kneller (2009) apply a Heckman sample selection gravity model to control for possible self-selection into exporting using firm-level data on the Swedish food and beverage sector. Crozet and Koenig (2010), in turn, examine the impact of distance on the probability of exporting and on export levels, using French manufacturing firm-level data. Belenkiy (2010) applies the two-stage Heckman procedure to estimate determinants of the extensive margin of exports from Organisation for Economic Cooperation and Development (OECD) countries to non-OECD countries and Portugal-Perez and Wilson (2012) apply it in terms of export performance of developing countries. Finally, Christen, Wolfmayr and Pfaffermayr (2013) examine the determinants of service exports in Austria at the firm/destination country-level using a Heckman sample selection gravity model.

Finally, there are a few papers that have studied the determinants of African trade using a gravity model. However, none of them has explored the role of extensive and intensive trade margins. Eita (2008) analyses the determinants of Namibian exports using a gravity model framework. Similarly, Jordaan and Eita (2011) investigate the determinants of South Africa's exports of wood and articles of wood using a gravity model approach. The results of the latter analysis suggest that there is unexploited trade potential among some of South Africa's trading partners such as Canada, the United States, Comoros, Germany, Greece, Italy, Ireland, New Zealand, Russia and Tanzania. Márquez-Ramos (2007) explores the determinants of trade for South Africa and Ghana, respectively, using disaggregated data by sector. The author asserts that technological innovation and geographical and social factors play a key role in South Africa's trading relationships with other countries.

\section{Empirical specification Data}

This paper uses South African exports disaggregated by product in 2012, with the data sourced from the United Nations' Comtrade Database. This database provides export data from a particular exporting country to an importing country disaggregated by product up to Harmonised System 6-digit level (HS6). Export data are classified per HS cluster, similar to the approach in Smet (2007). The groupings of HS6level products are listed in Table 1.

Table 1 presents the range of products that South Africa exported in 2012, classified by industry and export value. It can be observed that South Africa exports more than $95 \%$ of the 5039 products classified in chapters Foodstuff and Plastics and rubbers and exports less than $78 \%$ of Mineral products and Raw hides, skins, leather and furs. Although South Africa exports a wide variety (around 87\%) of products according to the HS6 classification, the value of many of the products in the export mix is very low. Indeed, only $53.7 \%$ of the products exported are valued at more than US\$100 000, while only $24.8 \%$ of products are valued at more than US\$1 000000 .

Table 2 presents the percentage of positive export flows by product category. Given a total of 196 importing countries and 5039 products (987 644 possible export flows), South Africa delivers only 93592 positive export flows (9.5\%).

Detailed results of export flows in terms of products and destinations show that other African countries such as Zimbabwe, Zambia, Mozambique and the Democratic Republic of Congo are the recipients of more than $67 \%$ of South Africa's exports, while countries such as Yemen, Puerto Rico, Sudan and Palau are not among South Africa's export

TABLE 1: Varieties of products exported by industry (2012)

\begin{tabular}{|c|c|c|c|c|c|c|c|}
\hline Industry (HS chapters) & Total products & $\begin{array}{l}\text { Products with } \\
\text { positive exports }\end{array}$ & $\%$ & $\begin{array}{c}\text { Products with exports } \\
>\text { US } \$ 100000\end{array}$ & $\%$ & $\begin{array}{l}\text { Products with exports } \\
>\text { US\$1 } 000000\end{array}$ & $\%$ \\
\hline $\begin{array}{l}\text { Animal and animal products } \\
(0100-0599)\end{array}$ & 194 & 177 & 91.2 & 95 & 49.0 & 48 & 24.7 \\
\hline $\begin{array}{l}\text { Vegetable products } \\
\text { (0600-1599) }\end{array}$ & 323 & 285 & 88.2 & 159 & 49.2 & 82 & 25.4 \\
\hline Foodstuffs (1600-2499) & 181 & 173 & 95.6 & 132 & 72.9 & 79 & 43.6 \\
\hline Mineral products (2500-2799) & 170 & 131 & 77.1 & 84 & 49.4 & 55 & 32.4 \\
\hline $\begin{array}{l}\text { Chemicals and allied industries } \\
\text { (2800-3899) }\end{array}$ & 760 & 664 & 87.4 & 372 & 48.9 & 172 & 22.6 \\
\hline $\begin{array}{l}\text { Plastics and rubbers } \\
(3900-4099)\end{array}$ & 189 & 185 & 97.9 & 139 & 73.5 & 65 & 34.4 \\
\hline $\begin{array}{l}\text { Raw hides, skins, leather and } \\
\text { furs (4100-4399) }\end{array}$ & 74 & 51 & 68.9 & 36 & 48.6 & 15 & 20.3 \\
\hline $\begin{array}{l}\text { Wood and wood products } \\
\text { (4400-4999) }\end{array}$ & 228 & 189 & 82.9 & 128 & 56.1 & 54 & 23.7 \\
\hline Textiles (5000-6399) & 809 & 640 & 79.1 & 201 & 24.8 & 37 & 4.6 \\
\hline $\begin{array}{l}\text { Footwear and headgear } \\
(6400-6799)\end{array}$ & 55 & 47 & 85.5 & 28 & 50.9 & 4 & 7.3 \\
\hline Stone and glass (6800-7199) & 190 & 175 & 92.1 & 117 & 61.6 & 52 & 27.4 \\
\hline Metals (7200-8399) & 587 & 508 & 86.5 & 373 & 63.5 & 198 & 33.7 \\
\hline $\begin{array}{l}\text { Machinery and electrical } \\
\text { (8400-8599) }\end{array}$ & 762 & 709 & 93.0 & 548 & 71.9 & 264 & 34.6 \\
\hline Transportation (8600-8999) & 132 & 123 & 93.2 & 106 & 80.3 & 70 & 53.0 \\
\hline Miscellaneous (9000-9799) & 385 & 320 & 83.1 & 186 & 48.3 & 55 & 14.3 \\
\hline Total & 5039 & 4377 & 86.9 & 2704 & 53.7 & 1250 & 24.8 \\
\hline
\end{tabular}


TABLE 2: Percentage of non-zero export flows by industry (2012).

\begin{tabular}{lccc}
\hline Industry & Flows & Positive & \% \\
\hline Animal and animal products & 38024 & 2073 & 5.5 \\
Chemicals and allied industries & 148960 & 10460 & 7.0 \\
Foodstuffs & 35476 & 4771 & 13.4 \\
Footwear/headgear & 10780 & 1246 & 11.6 \\
Machinery/electrical & 149352 & 21384 & 14.3 \\
Metals & 115052 & 12142 & 10.6 \\
Mineral products & 33320 & 1920 & 5.8 \\
Miscellaneous & 75460 & 8651 & 11.5 \\
Plastics/rubbers & 37044 & 5031 & 13.6 \\
Raw hides, skins, leather and furs & 14504 & 1285 & 8.9 \\
Stone/glass & 37240 & 3478 & 9.3 \\
Textile & 158564 & 8674 & 5.5 \\
Transportation & 25872 & 3107 & 12.0 \\
Vegetable products & 63308 & 5049 & 8.0 \\
Wood and wood products & 44688 & 4321 & 9.7 \\
\hline Total & 987644 & 93592 & 9.5 \\
\hline
\end{tabular}

destinations. ${ }^{1}$ Indeed, South Africa exports more than 20\% of the product categories to only 27 out of 196 countries and less than $5 \%$ of the product categories to 111 importing countries - pointing to a varied export product mix but a concentrated collection of export destinations. ${ }^{2}$ Clearly, there is potential for South Africa to expand the number of export markets. To this end, the determinants of South Africa's extensive margin should be identified.

\section{Methodology}

The gravity model has been the empirical approach to analysing the determinants of bilateral trade flows. The basic form of this model assumes that trade between countries can be equated to the gravitational pull between two objects because it is directly related to countries' size and inversely related to the distance between them.

Similar to the approach in Greenaway et al. (2009) and Christen et al. (2013), the empirical model in this paper is derived from the seminal paper of Helpman et al. (2008) whose model is based on the premise that firms are heterogeneous (as theorised by Melitz 2003), without using firm-level data. The gravity model is estimated with a twostage sample selection model using the estimation procedure proposed by Heckman (1979). For implementation purposes, two different equations are defined. The first equation (selection equation) addresses the zeros directly by modelling trade participation. This equation provides the variables that affect the extensive margin of trade, that is, factors that affect the probability that South Africa will export a product to a particular country. The second equation (outcome equation) models trade flows conditional on participation. This equation is specified as a traditional gravity model and explores the variables that affect the intensive margin of trade, that is, volume of export of a product to a particular country. Moreover, the Heckman procedure requires an identification variable that influences the probability of exporting, but not the volume, to comply 1.These results are available on request.

2.Table $\mathrm{A} 2$ in the appendix presents the main trading partner by industry. with the exclusion restriction. In line with Helpman et al. (2008) and supported by Martin and Pham (2008), an independent variable associated with the fixed trade costs of establishing trade flows (such as country-level data on regulations for establishing a new firm) was omitted from the outcome equation. ${ }^{3}$ Specifically included, though, were the cost (as a \% of countries' GDP per capita), the number of documents and the time required to establish a new firm.

The first stage in the model consists of a probit regression which explains the probability that South Africa will export to country $i$ (selection equation), where the dependent variable is a dummy that is equal to 1 if South Africa exports to country $i$. A latent variable $E_{i t}^{*}$ is defined to declare that South Africa is exporting $\left(E_{i}^{*}=1\right)$ or $\operatorname{not}\left(E_{i}^{*}=0\right)$ a particular importing country $i$. The second stage consists of a gravity equation estimated in logarithmic form, which explains the volume of exports from South Africa to $i$ (outcome equation) and incorporates a term based on estimates of the first stage, the inverse Mills ratio (IMR), to correct for the non-random prevalence of zero trade flows. In this second stage, the dependent variable is $\operatorname{LnExp}{ }_{i,}$ - that is, the logarithm of the volume of exports from South Africa to an importing country $i$. The database used in the study covers 196 importing countries in the year $2012 .{ }^{4}$

The selection (Eqn 1) and the outcome (Eqn 2) equations are as follows:

$E_{i}^{*}=\beta^{\prime} Z_{i}+\varepsilon_{i}$

[Eqn 1]

$\operatorname{Exp}_{i}=\left\{\begin{array}{c}\gamma^{\prime} \mathrm{W}_{\mathrm{i}}+\eta_{\mathrm{i}}, \text { if } \mathrm{E}_{\mathrm{i}}^{*}=1 \\ 0, \text { if } \mathrm{E}_{\mathrm{i}}^{*}=0\end{array}\right.$

where $W_{i}$ is a set of explanatory variables of the outcome equation with its corresponding parameters $\gamma^{\prime}$ while $Z_{i}$ are the explanatory variables included in the selection equation with the corresponding set of parameters $\beta^{\prime}$.

Included in vector $Z_{i}$ are both the explanatory variables in $W_{i}$ plus an exclusion restriction that affects only the fixed costs of exporting, not the variable trade costs - that is, a variable that determines the probability of exporting to a particular destination but not the volume of exports. As in previous studies, this study uses (as an exclusion restriction) a variable relating to firm entry cost in the importing country. ${ }^{5}$ Finally, $\varepsilon_{i}$ and $\eta_{i}$ are independent and identically distributed disturbance terms in the selection and outcome equations, respectively.

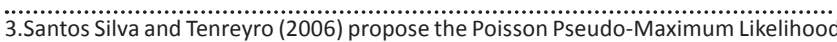
estimator to deal with heteroscedastic residuals and the prevalence of zeros in the dependent variables, which are undefined when the dependent variable is converted into logarithmic form. However, as shown by Martin \& Pham (2008), the Heckman sample selection procedure provides better estimates when an appropriated excluded variable is used in the first stage, such as the cost of establishing a new firm.

4.List of importing countries are presented in Table A1 in the appendix.

5.The main difficulty in this approach is to find an exclusion variable for the probit model (selection equation) that is exogenous to the trade value. Alternatively, religious similarity has also been considered as exclusion restriction and results are very similar. Estimates are available upon request. 
The error terms have a bivariate normal distribution with zero means, standard deviation $\sigma_{\varepsilon}$ and $\sigma_{\eta}$ and correlation $\rho$.

For exporting firms, the conditional expectation of the volume of exports can be derived as follows:

$$
\mathrm{E}\left[\operatorname{Exp}_{\mathrm{i}} \mid E_{i}^{*} \geq 0\right]=\alpha^{\prime} \mathrm{W}_{\mathrm{i}}+\rho \sigma_{\varepsilon} \lambda\left(\beta \mathrm{Z}_{i}\right)
$$

where $\lambda\left(\hat{\beta} Z_{i}\right)$ is the IMR. By including $\lambda$ in the outcome equation, there is control for sample selection bias. In particular, the proposed two-stage Heckman procedure adjusts the second stage of the regression for sample selection bias by incorporating the IMR to the gravity equation.

Table 3 presents a summary of the variables included in the analysis. The explanatory variables have been classified into eight categories: (1) Economic variables, which include importing country real GDP per capita and population to control for the extent of demand in the country; (2) Geographical variables, which affect trade costs such as the distance between South Africa and the importing country, whether the importing country shares a common land border with South Africa and whether it is an island or landlocked; (3) Cultural variables, which are used as a proxy for the cultural affinity between South Africa and the importing country. As the three main official languages in South Africa are Zulu, Afrikaans and English but the first two are largely only spoken within the country, the common language dummy variable considers countries where English is one of the official languages. Moreover, sharing a colonial background (i.e. with Namibia, the Netherlands and the United Kingdom) and a religion similarity index

TABLE 3: Variable definitions and sources.

\begin{tabular}{lll}
\hline Variable & Definition & Source \\
\hline Economic variables & & Logarithm of real GDP per capita of importer country i \\
Log of GDPpc & Logarithm of population of importing country $i$ & World Development Indicators (2011). \\
Ln of Pop &
\end{tabular}

\section{Geographical variables}

LnDist

Logarithm of distance (in $\mathrm{km}$ ) between South Africa and importing country

Border

Landl

Island

Cultural variables

Language

Religion

Colony

Political variables

Political stability

Embassies Dummy variable: value of 1 if South Africa shares a common land border with importing country, 0 otherwise

Dummy variable: value of 1 if importing country is landlocked, 0 otherwise

Dummy variable: value of 1 if importing country is an island, 0 otherwise

Dummy variable: value of 1 if importing country has English as one of its official languages, 0 otherwise Religious similarity index

Dummy variable that takes the value 1 if the importer country has a colonial relationship with South Africa, 0 otherwise

Political stability Indicator of destination/origin country. Ranges from -4 (less political stability) to 2 (more political stability)

Dummy variable: value of 1 if South Africa has an embassy in importing country, 0 otherwise

RTAs
EFTA
EUmmy variable: value of 1 for European Free Trade Association (EFTA) countries since the RTA
entered into force, 0 otherwise
Dummy variable: value of 1 for European Union (EU) countries since the RTA entered into force,
0 otherwise
Dummy variable: value of 1 for Southern African Development Community (SADC) countries since the
RTA entered into force, 0 otherwise

\section{Trade regulation}

Log of cost

Log of time

Log of document

\section{Regions}

North America

South America

North Africa

South Africa

East Europe

Asia

Oceania

Entry cost

Cost

Logarithm of official, administrative fees in dollars per imported container in country $i$ in year $t$

Logarithm of number of calendar days required to move a shipment from South Africa through importing country i's port in year $t$

Logarithm of number of documents required to move a shipment from South Africa through importing country i's port in year $t$

Dummy variable: value of 1 if importing country is in North America, 0 otherwise Dummy variable: value of 1 if importing country is in South America, 0 otherwise Dummy variable: value of 1 if importing country is in North Africa, 0 otherwise Dummy variable: value of 1 if importing country is in South Africa, 0 otherwise Dummy variable: value of 1 if importing country is in East Europe, 0 otherwise Dummy variable: value of 1 if importing country is in Asia, 0 otherwise Dummy variable: value of 1 if importing country is in Oceania, 0 otherwise

Dummy variable: value of 1 if relative cost to start a business is greater than the median for importing
GeoDist Database (Mayer \& Zignago 2011).

Rose (2011). Data available on Andrew K. Rose's website.
Data from World FactBook by the Central Intelligence Agency (2015).

GeoDist Database (Mayer \& Zignago 2011).

Worldwide Governance Indicators (Kaufmann, Kraay \& Mastruzzi 2010).

Rose (2005) completed with data from Department of International Relations and Cooperation.

RTA database by World Trade Organization (2012).
World Bank's Doing Business Survey (Djankov, Freund \& Pham 2010).

United Nations' Classification. country i, 0 otherwise

Days and Documents Dummy variable: value of 1 if sum of number of days
than the median for importing country $i, 0$ otherwise

RTA, Regional trade agreements; EFTA, European Free Trade Association; EU, European Union; SADC, Southern African Development Community. 
are included6; (4) Political variables, which consider an instability index in the importing country. This variable reflects perceptions about the likelihood of political instability and/or politically motivated violence, including terrorism, in the importing country. The existence of a South African embassy in the importing country, which could help facilitate new trade relationships and provide support to existing exporters, is also considered; (5) Regional trade agreements (RTAs), which control for existing trade agreements to which South Africa is a party; (6) Trade regulations, which influence the time and cost involved in moving a standard consignment of goods by sea from South Africa through the port of an importing country, and the number of documents needed to effect the transaction. Because the impact of the explanatory variables on South African trade margins is being estimated, it is not possible to add country-pair or importing country fixed effects to the equation because all explanatory variables are importing country-specific, so they would be absorbed by these fixed effects. An alternative is used, that is, (7) Regions, which denote various regions' fixed effects, using the United Nations' classification and with East Europe as the excluded category.

Finally, the Heckman procedure depends on a prior assumption of the validity of the exclusion restriction which is included in $W_{i}$ ut not in $Z_{i}$. As with Helpman et al. (2008) or Portugal-Perez and Wilson (2012), fixed regulation costs of firm entry are used (in the importing country), which should not affect a firm's export volumes and, furthermore, satisfies the exclusion restrictions of the twostage Heckman estimation method because it is excluded from the outcome equation in the second stage. Thus, a final category is included, called (8) Entry costs, which are considered in the selection equation only. Entry costs are measured by their effect on the number of days, the number of legal procedures and the relative cost (as a percentage of GDP per capita) involved in an entrepreneur legally starting up a business. Cost is defined as a binary indicator that equals 1 if the relative cost of starting a new business is greater than the median for the importing country $i$, 0 otherwise. Days and Documents is defined as a binary indicator that equals 1 if the sum of the number of days and procedures needed to start a business is greater than the median for the importing country i, 0 otherwise. The results of the empirical analysis are presented according to this disaggregation.

The Heckman procedure used in this paper, as in Helpman et al. (2008), presents the main limitation that is estimated for a cross-section. Consequently, time variation is not addressed, which may yield interesting results in terms of evaluating different trade policies such as reducing regulations or signing new trade agreements. Martinez-Zarzoso, Vidovic and Voicu (2014) adapt the Helpman et al. (2008) procedure to a panel data framework, and this can be considered as an extension for further research.

6. Religion Similarity Index is Relig $=\sum_{R=1}^{5} R_{S A} R_{i}$ where $\mathrm{R}$ is the percentage of affiliated population to each of the five major religions in South Africa and each affiliated population to each of
importing country, respectively.

\section{Extensive and intensive margins of South African exports}

As mentioned in an earlier section, products are classified by HS cluster, giving rise to 15 different sectors. Given a total of 987644 country-pair observations (3059 products $\times 196$ countries), 93592 of these present positive export flows $(9.5 \%$ of the sample). Although South Africa exports around $87 \%$ of the products, these are concentrated in just a few countries that vary depending on the type of product exported. So, a challenge for South Africa is to increase the number of export destination countries.

As a starting point, the Heckman procedure is applied to estimate export flows from South Africa disaggregated by industry. The model is estimated by maximum likelihood, and robust standard errors are computed.

Tables 4 and 4 Bis show the results of the estimate from the first stage (selection equation) of the Heckman procedure for all sectors pooled to the sample and the results disaggregated by sector. Marginal effects are reported. In general, the sign and significance of the coefficients are as expected. The economic variables that affect the extent of demand, namely GDP per capita and population, show a positive impact on the probability of exporting for all industries. Indeed, for all industries, a 1\% increase in GDP per capita or population in the importing country would increase the probability of exporting to that country by $0.034 \%$ and $0.038 \%$. In terms of geographical variables, the distance variable (suggesting higher transport costs) presents the expected negative sign. However, for some industries, distance either has no impact or even has a positive impact, such as Plastics and rubbers or Textiles. This result can be explained by the fact that the main trading partners for these products (such as China and the United States) are located far from South Africa. Moreover, when it comes to regional variables, the fact that the importing country is an island has a positive impact in some sectors, but if it is a landlocked country, there is the expected negative impact on the extensive margin. South Africa uses sea transport extensively for export purposes, so if an importing country has no port, the probability of South Africa exporting to that country is greatly reduced.

In terms of cultural variables, cultural proximity (expressed in terms of language and religion) has, for almost all sectors, a positive impact on the extensive margin. However, having a shared colonial history has no impact or even a negative impact on the probability of South Africa exporting goods from a range of sectors. When it comes to political variables, political stability in an importing country has a negative effect on the probability of exporting to that country. Such results can be somewhat controversial because they imply that South Africa is more likely to export to countries that are perceived to present a lower likelihood of political instability and/or politically motivated violence. However, on closer inspection of the data, it is evident that some of South Africa's main trading partners are in fact countries that have political 


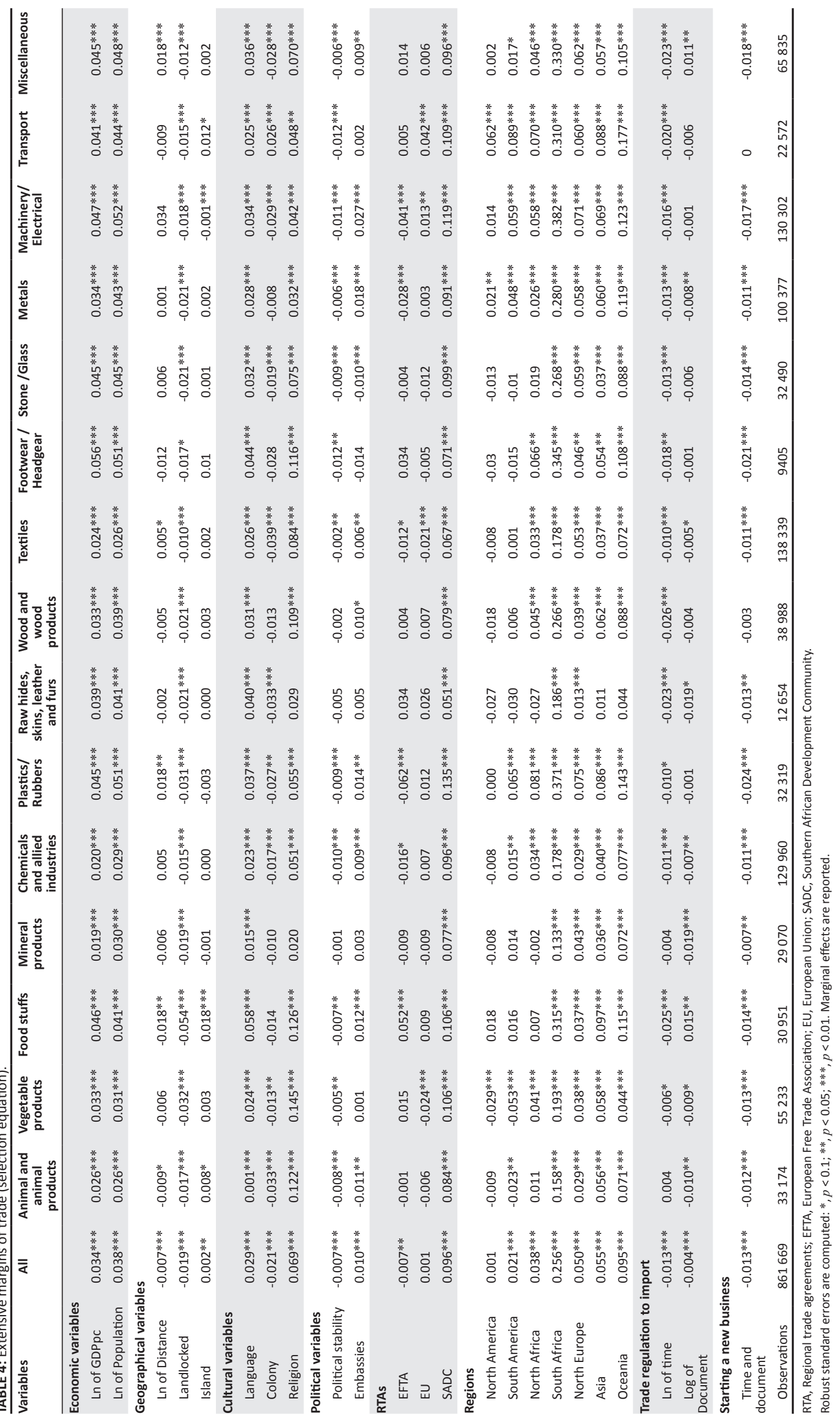


instability episodes, including China, India, Zambia, Zimbabwe and Mozambique.

An analysis of the impact of RTAs on the extensive margin of South African exports yields interesting results. Only the SADC Free Trade Agreement has had a significant and positive impact on the probability of South Africa exporting to other SADC members. This is not surprising, given their close proximity. Trade agreements with the EU and EFTA, in contrast, have not had a positive effect on the extensive margin. Considering that the excluded category is East Europe, countries located in Asia and Oceania show a higher probability of importing from South Africa.

Trade regulation variables generally have a negative impact on the probability of exporting. The more time-consuming and costly it is to export, the more difficult it is for local companies to be competitive and to access international markets. The time it takes to export is a decidedly negative factor for almost all industries, yet documentary requirements are not a significant obstacle for many industries. Moreover, it can be observed how the exclusion restriction in terms of time and documentation has the expected extremely negative impact on export-extensive margins in almost all industries. A trade facilitation drive aimed at shortening the time to export and reducing the documentary burden would generate new trading partners for South Africa.

The estimation results for the second stage, the outcome equation, are presented in Tables 5 and 5 Bis. The significant correlation $(\rho)$ highlights that the selection of firms for export purposes is systematic and needs to be considered in the econometric specification to consistently estimate the export flows. Sigma $(\sigma)$ is the estimator of the standard error of the residual in the outcome equation. The IMR is computed as $I M R=\rho^{*} \sigma$. As can be observed, $\rho$ is significant for 6 out of 15 industries. The Mills ratio is positive for all industries combined, as well as for 5 individual industries, while the ratio is negative for the remaining 10 industries. It is important to note that when the coefficient of the Mills ratio is positive, 'positive selection' is said to have occurred; if the coefficient is negative, then 'negative selection' is the result. Indeed, positive selection means that, without the correction, the estimate of the parameters of the outcome equation would have been upward biased, while negative selection would have resulted in a downward-biased estimate. In any case, the significance of the Mills ratio is that sample selection bias exists and needs to be controlled.

In general, the variables that affect the extensive margin of trade also affect the intensive margin, although many of these variables are not significant, depending on the industry considered. As predicted by the gravity model, the economic size of the importing country, measured in terms of GDP per capita and population, is an important factor in explaining the volume of South Africa's exports. However, these variables produce a negative impact on some sectors, such as Mineral products, Plastics and rubbers or Machinery and electrical products. In this regard, the main trading partners for these industries are not necessarily countries with high per capita income levels, that is, China, India, Georgia, Hungary or Czech Republic.

When all industries are considered, geographical variables present the expected negative sign; however, differences in the significance of the coefficients can be observed by industry. As for the extensive margin, distance and being an island present the expected negative sign when the variables are significant, while being a landlocked country (which rules out sea transport) negatively affects the volume of exports. Regarding cultural variables, having a common language or religion has a positive effect on the volume of exports if the variables are significant. Sharing the same colonial background has a negative impact when all industries are considered, but interestingly, the sign of the coefficients changes for some industries when the sector classification is used.

Political instability has a negative effect on all industries when the variable is significant, while having an embassy in the importing country has no effect or even a negative effect on export volumes. In similar vein to the extensive margin, the only trade agreement that delivers a positive effect on export volumes is the SADC Free Trade Agreement, and only in respect of some industries. Jordaan and Eita (2011), for example, found that the EU and NAFTA trade agreements have not led to an increase in South African exports. Finally, trade regulations that influence the time to export have a negative impact on the volume of exports if the variable is significant. Conversely, the number of documents required to export has a positive impact on some industries where the variable is significant. This contradictory result might be because of both the trade regulation variables being highly correlated, suggesting that the most important variable affecting the volume of exports is time to export. Consequently, the South African government should give priority attention to streamlining the regulatory aspects of export logistics.

The analysis reveals the most relevant determinants of exports by industry, offering a useful platform from which policymakers can formulate appropriate strategies for what they consider to be high-priority sectors and products.

\section{Summary of key findings and concluding remarks}

South Africa's DTI has long been of the view that South Africa needs to boost and diversify its exports - in other words, expand exports in both the intensive and extensive margins. The paper set out to reveal the key determinants influencing South Africa's extensive and intensive trade margins, thereby highlighting key opportunity areas and overarching shortcomings in the country's policy, regulatory and physical environments. This was done by employing a Heckman selection gravity model, using highly disaggregated data for 2012 (at HS6 level). The first 


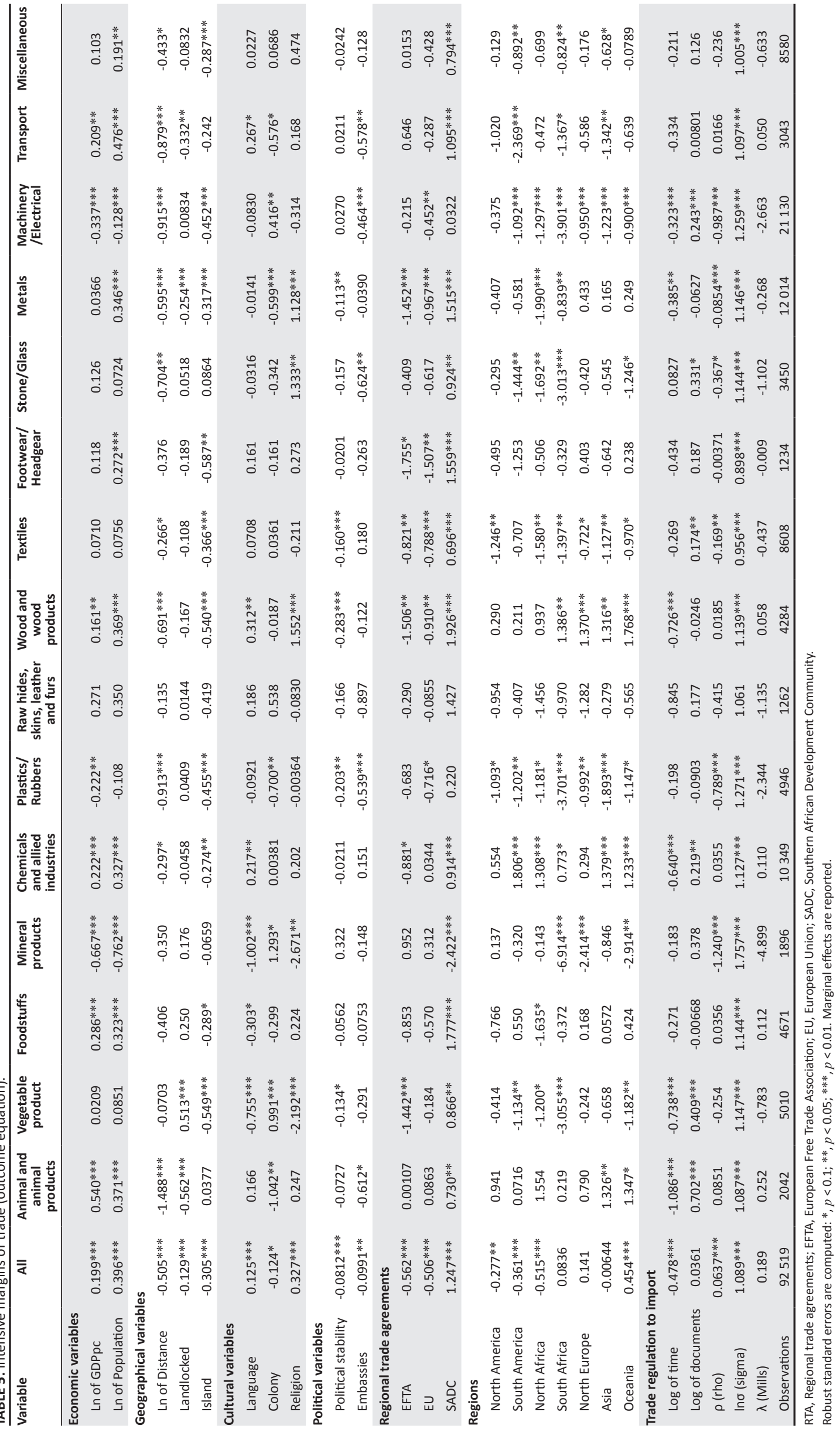


stage of the process revealed the factors affecting the probability of South Africa exporting to a particular destination (extensive margin). The second stage, which modelled trade flows, revealed the variables that affect export volumes (intensive margin).

The key results from the study indicate that South Africa exports an extensive range of products to a limited number of countries, which reinforces the benefit of performing a trade (and especially export) margin analysis. The specific results, in turn, reveal how a wide range of market access determinants affect South Africa's export growth and potential exporter profitability. In terms of the probability to export, or the extensive margin, economic variables such as the importing country's GDP and population have a positive impact on the firms' decision to export. This highlights the importance of firms focusing their exporting endeavours on export markets with growing demand. In order to do so, it is important that they have access to reliable and affordable information about export opportunities in growing markets. Here information support systems such as the Decision Support Model, which identifies realistic export opportunities for South African exports, is a useful tool for both regional and national export promotion agencies (for details, see Cuyvers, Steenkamp \& Viviers 2012).

Other factors affecting the extensive margin are distance to the market (negative impact), cultural/language fit (positive impact), presence of a South African embassy abroad (positive impact), existing free trade agreement with SADC (positive impact) and trade regulations and costs (negative impact). These results firstly emphasise the importance of investing in transport infrastructure in order to reduce the transport cost burden of exporting to distant markets. At the same time, trade facilitation initiatives (e.g. more streamlined trade regulations) should be rolled out to stimulate export growth in South Africa. This would also contribute to the deepening of trade within SADC and help to exploit the untapped potential to develop a system of regional value chains', as proposed by the World Bank (2014:37). Finally, industry-specific assistance from embassies based in foreign markets, especially those that are culturally distant, would help to give momentum to firms' export efforts.

In terms of the intensive margin (or factors influencing the volume of exports), there are strong parallels with the extensive margin, with the exception that the time involved in exporting has more of an impact than documentary requirements. This is also heavily dependent on the state of the infrastructure, the complexity of the regulatory apparatus and other factors such as congestion at ports and borders. This is in line with the World Bank's recommendations in 2014 that South Africa needed to seriously tackle its infrastructural bottlenecks [both of a physical and ICT (information and communication technology) nature] if it was to enhance its export competitiveness from a time and cost perspective and provide an environment in which small and medium-sized exporters could flourish and grow.
In conclusion, the dearth of adequate market-related information and other noted shortcomings in South Africa's infrastructure and regulatory environment (which add to the cost and time to export) could explain why the country's exports have largely developed in the intensive margin. If South Africa is to make sustainable inroads into more markets and expand its product offerings, the government and its economic partners need to seriously address the obstacles standing in the way, while also adopting an industry-based approach to export policymaking and promotion. Dissecting the industry-specific results would be an important part of this process and future research would involve developing counterfactual scenarios to assess the expected reaction of potential exporting firms' trade flows to changes in key exogenous determinants. Additionally, industry-specific research (that focuses on obtaining firm-level information) on market access and trade barriers would help industrybased approaches in policymaking as suggested above.

\section{Acknowledgements}

This work is based on the research supported in part by the National Research Foundation of South Africa (Grant Number 90709). Any opinion, finding and conclusion or recommendation expressed in this material is that of the authors and the NRF does not accept any liability in this regard.

\section{Competing interests}

The authors declare that they have no financial or personal relationships that may have inappropriately influenced them in writing this article.

\section{Authors' contributions}

M.M. constructed the introduction, literature review and conclusion. M.S-G. constructed the empirical specification, methodology and results.

\section{References}

Amurgo-Pacheco, A. \& Pierola, M.D., 2008, Patterns of export diversification in developing countries: Intensive and extensive margins, Working Paper No. 4473 World Bank Policy Research, Washington, DC.

Baier, S.L., Bergstrand, J.H. \& Feng, M., 2013, 'Economic integration agreements and the margins of international trade', Journal of International Economics 93(2), 339-350. https://doi.org/10.1016/j.jinteco.2014.03.005

Belenkiy, M., 2010, The extensive margin in the industry trade: Estimation, significance and implications, Working Paper, University of California, Santa Cruz, CA, viewed 8 August 2015, from http://www.eiit.org/WorkingPapers/Papers/TradePatterns/ FREIT076.pdf

Bezuidenhout, C., Matthee, M., Naugthin, T. \& Rankin, N., 2015, 'An investigation of exporting and productivity amongst South African firms', 'Paper Presented at the Economic Society of South Africa (ESSA) Conference, Cape Town, 2-4 September 2015.

Chaney, T., 2008, 'Distorted gravity: The intensive and extensive margins of international trade', The American Economic Review 98, 1707-1721. https://doi. international trade', The Amer.10.1257/aer.98.4.1707
org

Christen, E., Wolfmayr, Y. \& Pfaffermayr, M., 2013, Decomposing service exports adjustments along the intensive and extensive margin at the firm-level, FIW Research Reports series IV-005, FIW. Center of Excellence on International Trade, Vienna.

Crozet, M. \& Koenig, P., 2010, 'Structural gravity equations with intensive and extensive margins', Canadian Journal of Economics 43(1), 41-62. https://doi. org/10.1111/j.1540-5982.2009.01563.x

Cuyvers, L., Steenkamp, E. \& Viviers, W., 2012, 'The methodology of the decision support model (DSM)', in L. Cuyvers \& W. Viviers (eds.), Export promotion: A decision support model approach, pp. 53-80, Sun Press, Stellenbosch, South Africa. 
Debaere, P. \& Mostashari, S., 2010, 'Do tariffs matter for the extensive margin of international trade? An empirical analysis', Journal of International Economics 81(2), 163-169. https://doi.org/10.1016/j.jinteco.2010.03.005

Department of Trade and Industry (DTI), 2013, National exporter development programme, viewed 5 February 2017, from http://fishsa.org/files/Skills Development/national_exporter_development_programme.pdf

Djankov, S., Freund, C. \& Pham, C., 2010, 'Trading on time', The Review of Economics and Statistics 92(1), 166-173. https://doi.org/10.1162/rest.2009.11498

Dutt, P., Mihov, I. \& Van Zandt, T., 2011, Does WTO matter for the extensive and the intensive margins of trade? Discussion Paper No. 8293, 'Centre for Economic Policy Research, London.

Eita, H., 2008, Determinants of Namibian exports: A gravity model', Working Paper 13th Annual Conference for Econometric Modeling in Africa, University of Pretoria, viewed 10 June 2015, from http://www.africametrics.org/documents/ conference08/day1/session2/eita.pdf

Felbermayr, G. \& Kohler, W., 2006, 'Exploring the intensive and extensive margins of world trade', Review of World Economics 142(4), 642-674.

Greenaway, D., Gullstrand, J. \& Kneller, R., 2009, Firm heterogeneity and the geography of international trade, AgriFood Working Paper 2009, 2, Agrifood Economics Centre, Lund, Sweden.

Heckman, J.J., 1979, 'Sample selection bias as a specification error', Econometrica 47 153-161. https://doi.org/10.2307/1912352

Helpman, E., Melitz, M. \& Rubenstein, Y., 2008, 'Estimating trade flows: Trading partners and trading volumes', The Quarterly Journal of Economics 123, 441-487. https://doi.org/10.1162/qjec.2008.123.2.441

Johannsen, F. \& Martínez-Zarzoso, I., 2014, Political determinants of the extensive and intensive margins of international arms transfers, Discussion Papers No. 228, Ibero America Institute for Economic Research, Georg-August-Universität, Göttingen.

Jordaan, A. \& Eita, H., 2011, 'Identifying South Africa's wood exports potential using a gravity model', 2010 International Conference on E-business, Management and Economics IPEDR, vol. 3, 33. IACSIT Press, Hong Kong from http://www.ipedr.com/ vol3/33-M00052.pdf

Kaufmann, D., Kraay, A. \& Mastruzzi, M., 2010, The worldwide governance indicators: Methodology and analytical issues, Policy Research Working Paper Series 5430 The World Bank, Washington, DC.

Lawless, M., 2010, 'Deconstructing gravity: Trade costs and extensive and intensive margins', Canadian Journal of Economics 43(4), 1149-1172. https://doi. org/10.1111/j.1540-5982.2010.01609.x

Márquez-Ramos, L., 2007, Understanding the determinants of international trade in African countries: An empirical analysis for Ghana and South Africa', Instituto de Economía Internacional, Universitat Jaume I, viewed 5 February 2017, from https:// sta.uwi.edu/conferences/salises/documents/Marquez-Ramos $\% 20 \% 20 \mathrm{~L}$.pdf

Martin, W. \& Pham, C.S., 2008, Estimating the gravity model when zero trade flows are frequent and economically determined, Policy Research Working Paper No. 7308. World Bank, Washington, DC.

Martínez-Zarzoso, I., Vidovic, M. \& Voicu, A., 2014, EU-Accession effects on sectora trade: A Helpman-Melitz-Rubinstein approach with panel data, CESifo Working Paper Series No.4903, CESifo, Munich, Germany.
Matthee, M., Farole, T., Naughtin, T. \& Rankin, N., 2016, 'South African exporters and the global crisis: Intensive margin shock, extensive margin hangover', South African Journal of Economics 84(2), 183-198.

Matthee, M., Idsardi, E. \& Krugell, W.F., 2016, 'Can South Africa sustain and diversify its exports?', South African Journal of Economic and Management Sciences 19(2), 249-263. https://doi.org/10.17159/2222-3436/2016/v19n2a6

Mayer, T. \& Zignago, S., 2011, Notes on CEPII's distances measures: The GeoDist database, CEPII Working Paper 2011-25., CEPII Research Center, France.

Melitz, M.J., 2003, 'The impact of trade on intra-industry reallocations and aggregate industry productivity', Econometrica 71, 1695-1725. https://doi.org/10.1111/ 1468-0262.00467

Melitz, M.J. \& Redding, S.J., 2012, 'Heterogeneous firms and trade', NBER Working Paper no. 18652, National Bureau of Economic Research, Cambridge.

Portugal-Perez, A. \& Wilson, J.S., 2012, 'Export performance and trade facilitation reform: Hard and soft infrastructure', World Development 40(7), 1295-1307. https://doi.org/10.1016/j.worlddev.2011.12.002

Rose, A.K., 2005, The foreign service and foreign trade: Embassies as export promotion, NBER Working Paper no. 11111, viewed 1 June 2015, from http://faculty.haas. berkeley.edu/arose/RecRes.htm\#Software

Rose, A.K., 2011, 'The Olympic effect', The Economic Journal 121(553), 652-677, viewed 1 June 2015, from http://faculty.haas.berkeley.edu/arose/RecRes. htm\#Software

Santos Silva, J. \& Tenreyro, S., 2006, 'The log of gravity', The Review of Economics and Statistics 88, 641-658. https://doi.org/10.1162/rest.88.4.641.

Smet, K., 2007, Stuck in the middle? The structure of trade between South Africa and its major trading partners, viewed 8 August 2015, from http://epub.wu.ac. at/876/

Steenkamp, E., Grater, S. \& Viviers, W., 2015, 'Streamlining South Africa's export development efforts in sub-Saharan Africa: A decision support model approach', viewed 5 February 2017, from https://www.wto.org/english/res_e/booksp_e/ viewed 5 February 2017, from https:

The Central Intelligence Agency, 2015, The World Factbook, viewed 1 June 2015, from https://www.cia.gov/library/publications/the-world-factbook/

Viviers, W., Cuyvers, L., Steenkamp, E.A., Grater, S., Matthee, M. \& Krugell, W.F. 2014, 'Identifying new product and service export opportunities for South Africa using a decision support model' International Business and Economics Africa using a decision support model' International Business and Economics Research
v13i6.8930

World Bank, 2014, South Africa economic update: Focus on export competitiveness, Issue No. 5., The World Bank, Washington, DC.

World Bank Group, Africa Regional Poverty Reduction and Economic Management, The World Bank, Washington, DC.

World Development Indicators, 2011, The World Bank, Washington, DC, views 10 June, from http://data.worldbank.org/data-catalog/world-development-indicators

World Trade Organization, 2012, The regional trade agreement database, viewed 1 June 2015, from http://rtais.wto.org/Ul/PublicMaintainRTAHome.aspx 


\section{Appendix 1}

TABLE 1-A1: List of importing countries.

\begin{tabular}{|c|c|c|c|}
\hline Afghanistan & Denmark & Kuwait & Puerto Rico \\
\hline Albania & Djibouti & Kyrgyz Republic & Qatar \\
\hline Algeria & Dominica & Lao PDR & Romania \\
\hline American Samoa & Dominican Republic & Latvia & Russian Federation \\
\hline Andorra & Ecuador & Lebanon & Rwanda \\
\hline Angola & Egypt, Arab Republic & Lesotho & Samoa \\
\hline Antigua and Barbuda & El Salvador & Liberia & San Marino \\
\hline Armenia & Eritrea & Liechtenstein & Saudi Arabia \\
\hline Australia & Estonia & Lithuania & Senegal \\
\hline Austria & Ethiopia & Luxembourg & Seychelles \\
\hline Azerbaijan & Faeroe Islands & Macao & Sierra Leone \\
\hline Bahamas, The & Fiji & Madagascar & Singapore \\
\hline Bahrain & Finland & Malawi & Slovak Republic \\
\hline Bangladesh & France & Malaysia & Slovenia \\
\hline Belarus & Gabon & Mali & Somalia \\
\hline Belgium & Gambia, The & Malta & Spain \\
\hline Belize & Georgia & Marshall Islands & Sri Lanka \\
\hline Benin & Germany & Mauritania & Sudan \\
\hline Bermuda & Ghana & Mauritius & Suriname \\
\hline Bhutan & Greece & Mexico & Swaziland \\
\hline Bolivia & Greenland & Micronesia & Sweden \\
\hline Bosnia and Herzegovina & Grenada & Moldova & Switzerland \\
\hline Botswana & Guam & Monaco & Syrian Arab Republic \\
\hline Brazil & Guatemala & Mongolia & Tajikistan \\
\hline Brunei & Guinea & Morocco & Tanzania \\
\hline Bulgaria & Guinea-Bissau & Mozambique & Thailand \\
\hline Burkina Faso & Guyana & Myanmar & Togo \\
\hline Burundi & Haiti & Namibia & Tonga \\
\hline Canada & Hungary & New Caledonia & Turkey \\
\hline Cape Verde & Iceland & New Zealand & Turkmenistan \\
\hline Cayman Islands & India & Nicaragua & Turks and Caicos \\
\hline Central African Republic & Indonesia & Niger & Tuvalu \\
\hline Chad & Iran & Nigeria & Uganda \\
\hline Chile & Iraq & Northern Mariana & Ukraine \\
\hline China & Ireland & Norway & UAE \\
\hline Colombia & Israel & Oman & Ukraine \\
\hline Comoros & Italy & Pakistan & USA \\
\hline Congo & Jamaica & Palau & Uruguay \\
\hline Congo, Democratic Republic & Japan & Panama & Uzbekistan \\
\hline Costa Rica & Jordan & Papua New Guinea & Vanuatu \\
\hline Cote d'Ivoire & Kazakhstan & Paraguay & Venezuela \\
\hline Croatia & Kenya & Peru & Vietnam \\
\hline Cuba & Kiribati & Philippines & Yemen \\
\hline Cyprus & Korea & Poland & Zambia \\
\hline Czech Republic & Korea, Democratic Republic & Portugal & Zimbabwe \\
\hline
\end{tabular}


TABLE 2-A1: Main importing countries by industry.

\begin{tabular}{|c|c|c|c|c|c|c|c|}
\hline \multirow{2}{*}{$\begin{array}{l}\text { All } \\
\text { Country }\end{array}$} & \multirow[b]{2}{*}{ Average exports } & \multicolumn{2}{|c|}{ Animal and animal products } & \multicolumn{2}{|c|}{ Vegetable products } & \multicolumn{2}{|c|}{ Foodstuffs } \\
\hline & & Country & Average exports & Country & Average exports & Country & Average exports \\
\hline China & 10485 & Spain & 2548 & Mexico & 53049 & Niger & 3094 \\
\hline Japan & 7812 & Italy & 2433 & Bangladesh & 6299 & Algeria & 2755 \\
\hline India & 3892 & Cameroon & 2120 & The Netherlands & 5865 & Japan & 2672 \\
\hline USA & 3818 & Portugal & 2082 & Russia & 5353 & Sweden & 2612 \\
\hline Korea & 3488 & Fiji & 1838 & UK & 3401 & Germany & 2229 \\
\hline The Netherlands & 2416 & Hong Kong & 1674 & Malaysia & 2983 & UK & 2140 \\
\hline Germany & 2360 & Australia & 1069 & Hong Kong & 2791 & Syria & 2024 \\
\hline \multicolumn{2}{|l|}{ Mineral products } & \multicolumn{2}{|c|}{ Chemicals and allied industries } & \multicolumn{2}{|c|}{ Plastics/rubbers } & \multicolumn{2}{|c|}{ Raw hides, skins, leather and furs } \\
\hline Country & Average exports & Country & Average exports & Country & Average exports & Country & Average exports \\
\hline China & 214858 & USA & 3289 & Brazil & 2431 & Italy & 2577 \\
\hline India & 61668 & Belgium & 3052 & China & 1627 & China & 1543 \\
\hline Finland & 48581 & Brazil & 2395 & Paraguay & 1396 & Korea & 1402 \\
\hline Korea & 42897 & The Netherlands & 2019 & Zambia & 1176 & Bulgaria & 1366 \\
\hline Japan & 38113 & Japan & 1673 & Zimbabwe & 965 & Vietnam & 793 \\
\hline The Netherlands & 33291 & Lithuania & 1656 & $\begin{array}{l}\text { Congo, Democratic } \\
\text { Republic }\end{array}$ & 824 & Brazil & 740 \\
\hline \multicolumn{2}{|c|}{ Wood and wood products } & \multicolumn{2}{|c|}{ Textiles } & \multicolumn{2}{|c|}{ Footwear/headgear } & \multicolumn{2}{|c|}{ Stone/glass } \\
\hline Country & Average exports & Country & Average exports & Country & Average exports & Country & Average exports \\
\hline Indonesia & 11852 & Czech Republic & 3763 & Argentina & 307 & Japan & 72918 \\
\hline Japan & 5956 & China & 2876 & Brazil & 287 & Switzerland & 34228 \\
\hline China & 4789 & Bangladesh & 1013 & Zimbabwe & 206 & Hong Kong & 17385 \\
\hline Thailand & 3832 & Indonesia & 962 & Hong Kong & 204 & USA & 16502 \\
\hline Belgium & 1538 & India & 531 & Zambia & 187 & Belgium & 15007 \\
\hline India & 1234 & Italy & 452 & Lebanon & 179 & UK & 14325 \\
\hline Argentina & 952 & Bulgaria & 412 & Indonesia & 173 & Israel & 12791 \\
\hline \multicolumn{2}{|l|}{ Metals } & \multicolumn{2}{|c|}{ Machinery/electrical } & \multicolumn{2}{|c|}{ Transportation } & \multicolumn{2}{|c|}{ Miscellaneous } \\
\hline Country & Average exports & Country & Average exports & Country & Average exports & Country & Average exports \\
\hline Japan & 10564 & Georgia & 2555 & USA & 35635 & Bulgaria & 7141 \\
\hline Korea & 7697 & Hungary & 1453 & Russia & 23002 & USA & 812 \\
\hline USA & 4393 & Czech Rep. & 1420 & Germany & 19180 & Brunei & 396 \\
\hline India & 4053 & USA & 1395 & Japan & 10497 & Czech Republic & 286 \\
\hline Malaysia & 3566 & Poland & 1227 & Tunisia & 6918 & Spain & 272 \\
\hline The Netherlands & 3361 & Zambia & 1177 & Belgium & 6618 & Zambia & 252 \\
\hline
\end{tabular}

